\title{
Serum LP(a) Levels in African Aboriginal Pygmies and Bantus, Compared with Caucasian and Asian Population Samples
}

\author{
C. Cobbaert, ${ }^{, *}$ P. Mulder, ${ }^{2}$ J. Lindemans, ${ }^{1}$ and H. Kesteloot ${ }^{3}$ \\ 'Central Cuinical Chemical Laboratory, Dijkzigt Hospital, 3015 GD Rotterdam, The Netherlands, \\ ${ }^{2}$ Department of Epidemiology and Biostatistics, Erasmus University, 3015 GD Rotterdam, The Netherlands, \\ and ${ }^{3}$ Department of Epidemiology and Brostatistics, University Hospital Leuven, 3000 Leuven, Belgium
}

\begin{abstract}
Serum lipoprotein(a) ( $\mathrm{L} p(\mathrm{a})$ ) and its correlates were studied in African Aboriginal Pygmies $(n=146)$ and Bantus $(n=208)$ from Cameroon. Geometric mean Lp(a) levels were 274 and $289 \mathrm{mg} / \mathrm{l}$ in Bantu males and females, respectively, and 220 and $299 \mathrm{mg} / \mathrm{l}$ in Pygmy males and females, the gender difference being significant in Pygmies ( $p=0.024)$. In Pygmies $41 \%$ and $52 \%$ of the males and females, respectively, had Lp(a) levels above $300 \mathrm{mg} / \mathrm{l}$, compared with $47 \%$ and $55 \%$ in Bantus. Overall, Lp(a) levels did not significantly differ between Pygmies and Bantus, and did not correlate with age, body mass index (BMI), systolic and diastolic blood pressure. Compared with healthy Asian and Caucasian population samples, age- and BMI-adjusted geometric Lp(a) means were 2.3- to 5.0-fold higher in Pygmy and Bantu males, and 2.9- to 3.6-fold higher in Pygmy and Bantu females $(p \leq 0.05$ ). Arross the population samples studied ethnicity predicted $12 \%$ and $17 \%$ of serum $L_{p}$ (a) variance in males and females, respectively. J curn Eprdemiol 50;9:1045-1053, 1997. (C) 1997 Elsevier Science Inc.
\end{abstract}

KEY WORDS. Lipoprotein(a), cholesterol, Pygmy, Bantu, Caucasian, Asian

\section{INTRODUCTION}

Lipoprotein(a) ( $\left.\mathrm{I}_{\mathrm{p}}(\mathrm{a})\right)$ is a cholesterol-rich complex lipoprotein macromolecule, consisting of a low density lipoprotein (LDL)-like particle attached by a disulfide bond to a unique glycoprotein, i.e., apolipoprotein(a) (apo(a)) [1]. Apo(a) is unique because of its structural analogy with plasminogen [2], and its size and functional polymorphism [3,4]. Most studies reported that serum Lp(a) levels are mainly genetically determined - variation at the apo(a) locus contributing to this heritability - and are hardly influenced by lifestyle, diet, or drugs [1,5-9]. On the other hand, a few studies have shown that the serum Lp(a) level is correlated with other variables, such as age [10-12], sex [11], smoking [10], blood pressure [13], waist-to-hip ratio [10], impaired glucose tolerance [14-16], proteinuria [17], fibrinogen levels $[13,18,19]$, and use of medication [20,21].

So far, and despite the fact that $\mathrm{Lp}(\mathrm{a})$ had an attraction upon researchers like a "femme fatale," its physiological function is, 34 years after its discovery, still not unraveled. From experimental observations it is hypothesized that the cholesterol-rich Lp(a) lipoprotein particle probably exports

\footnotetext{
"Address for correspondence: Dr. C. Cobbacrt, Central Clinical Chemical Laboratory, Dijkzigt Hospital, Dr. Molewaterplein 40, 3015 GD Rotterdam, The Netherlands.

Accepted for publication on 22 Octuber 1996.
}

cholesterol out of the liver providing a continuous peripheral supply of such Lp(a)-cholesterol, which is independent from diet and other factors and which is reflected by the highly stable $\mathrm{Lp}(\mathrm{a})$ concentration over long-time periods [22]. The most likely targets of $\mathrm{Lp}(\mathrm{a})$-cholesterol are endocrine organs with high steroid hormone production. More is known about its pathophysiogical role. First, numerous epidemiological and clinical studies, mainly in Caucasians, demonstrated that $L p(a)$ was an independent risk factor for coronary heart disease (CHD) [6,23], stroke [24], and preclinical athcrosclerosis [25]. Second, Rath et al. [26] demonstrated Lp(a) depositions in the vessel wall of grafted arteries of coronary bypass patients, and found an association with serum Lp(a) levels. Third, it is postulated that elevated Lp(a) levels might interfere with fibrinolysis, due to its structural analogy with plasminogen $[27,28]$. Therefore, an elevated $L_{p}(a)$ level is considered to be a risk factor for both atherogenesis and thrombogenesis, at least in Caucasians $[1,6,23]$.

Lipoprotein(a) is an inherited CHD risk factor which, to our knowledge, has not been investigated in. Aboriginal African Pygmies yet $[1,6]$. Besides, knowledge of the genetic susceptibility of traditional populations may be valuable in order to anticipate future cardiovascular risks, especially if these populations would move from traditional lifestyles to more sedentary lifestyles [29-31]. After all, considerable ex- 
cess of coronary heart disease mortality and greatly increased prevalence of type 2 diabetes mellitus have been reported among expatriate "Westernized" Asian communities $[29,30]$ as well as in Aborigines from Western Australian in transition to urbanization and Westernization [31]. As only a few hunter-gatherer populations remain throughout the World, African Pygmies being one of them [3234], and as urbanization may occur in the future, it was decided to investigate the genetic susceptibility, i.e., serum Lp(a) levels, and lifestyle factors of traditional African Aboriginal Pygmy samples from South. West Cameroon, com. pared with Bantu samples from the same region. Because of the lack of international $\mathrm{Lp}$ (a) standardization [35], and to enable relative comparability across populations, serum $\mathrm{L}_{\mathrm{p}}$ (a) levels in Pygmies and Bantus were compared with those of Caucasian and Asian population samples.

The objectives of this cross-sectional study were, first, to provide descriptive data upon serum $L_{p}(a)$ levels in population-based samples of apparently healthy African Aboriginal Pygmies and neighboring Bantus, and to describe its relationships to other cardiovascular risk factors. Second, to compare serum $\mathrm{Lp}$ (a) concentrations in African Pygmies and Bantus to those in randomized Belgian, Hungarian, and Philippine population samples, displaying varying serum cholesterol levels and prevalences of CHD. Finally, to compare serum $\mathrm{Lp}(\mathrm{a})$ and serum cholesterol levels in Pygmies and Bantus with those in healthy and diseased Caucasians with overt CHD, respectively.

\section{MATERIALS AND METHODS Study Populations}

This study was part of a wider survey of health in Pygmy and Bantu populations in Cameroon, and was carried out in January through February 1994, and in May through June 1994 [33,34]. Non-fasting sera from Bantus and aboriginal Pygmies living in South-West Cameroon were obtained as described by Kestelout et al. [33,34]. Pygnies examined live in the tropical forests $3^{\circ}$ to $4^{\circ}$ north of the Equator in small communities of 60 to 100 individuals, including children. Two distinct Pygmy populations were investigated: One in the Mecasse region in the Dja reservation, consisting of three distinct communities spreaded out over a $30-\mathrm{km}$ distance. The second Pygmy population was living in the region of Lolodorf, at a distance of about $80 \mathrm{~km}$. The participation rate was estimated to be about $100 \%$ in three of the four Pygmy communities, whereas it was only $50 \%$ in the fourth Pygmy community due to a conflict of authority of part of the community to the tribal chief. Besides, three communities of neighboring Bantus were examined: one living in close contact with the Pygmies in the Mecasse region, one living in the Lolodorf region, and a separate community living in the village of Bengbis. In the Bantu population participation was essentially on a first-come, first-served basis due to time and blood sample collecting material restraints. Many more Bantus volunteered to participate but could not be accommodated. Consequently, it was impossible to examine a random sample of the population.

The Pygmies studied are pure hunter-gatherers, whereas the Bantus are agriculturers cultivating corn, manioc, and plantain. Since Fygmies do not know their age, the latter was estimated with the help of a Bantu teacher, by referral to important past events. Aftcr spccimen collcction and clot separation with a hand centrifuge, sera were frozen within eight hours and stored for maximum one month at $-20^{\circ} \mathrm{C}$, i.e., during the expedition period in Cameroon. Thereafter sera were shipped to Belgium and the Netherlands, stored at $-70^{\circ} \mathrm{C}$, and analyzed for serum $\mathrm{Lp}$ (a) within 8 months after sample collection.

Serum Lp(a) levels in Pygmies and Bantus were compared with fasting serum Lp(a) levels in Caucasian and Asian population samples (Belgians, $n=905$; Hungarians, $n=400$, and Philippines, $n=195$ ). All Caucasian and Asian specimens investigated were from unrelated, apparently healthy, and randomly selected subjects. Firstly, Belgian sera were obtained from age- and sex-matched 20- to 39-year-old employees from each Belgian province. Recruitment was done in the context of a cross-sectional study investigating the contribution of environmental and genetically determined cardiovascular risk factors to regional serum cholesterol and cardiovascular mortality differences in Belgium (manuscript in preparation). Hitherto, employees of different sociocconomic status were invited to participate in this study, prior to a scheduled medical check-up. Previous randomization and subsequent invitation, and medical check-up were conducted by the Flemish IDEWE and the Wallonian CeSI, two "Centres de Services Interenterprises-Médecine du Travail". Informed consent was obtained from all participants. Individual questionnaires were distributed during the medical check-up; volunteers were invited to fill in their identity, home address, nationality, and to indicate their smoking, drinking, dietary and lifestyle habits, education and profession, use of hormonal contraception, consumption of lipid lowering or other medication, and so forth. The filled-in questionnaire was checked by the physician who did the medical check-up, and completed if necessary. In addition, height and weight, as well as blood pressure were measured by the physician. As the Belgian study group is well documented, it was used as a reference population sample in this comparative $\mathrm{L} p$ (a) study. Randomized Hungarian samples were obtained via the National Institute of Food Hygiene and Nutrition, Budapest, Hungary [36], and were from adults living in Budapest, and in three different Hungarian regions, i.e., Fejér, Békés, Komárom-Esztergom. Philippine sera were from free-living individuals on Cebu Island and were randomized and obtained via the Philippine Heart Center in Quezon City.

Sera from diseased Caucasians were from unrelated Belgian male patients who underwent elective coronary artery 
bypass grafting (CABG) $(n=100)$ as described previously [37], or presented with an acute myocardial infarction $(n=$ 50) as diagnosed by WHO criteria. In the diseased group, serum $\mathrm{Lp}(\mathrm{a})$ was determined the day before bypass in the CABG patient group, and within 6 hours after onset of chest pain in the AMI patient group. All CABG and AMI patients included were free of insulin-dependent diabetes, renal insufficiency, cerebrovascular accidents, and liver disease. Notable is that in the CABG study group, only patients with preoperative serum cholesterol values between 4.66 and $7.24 \mathrm{mmol} / \mathrm{l}$ were included [37]. These highly selected, diseased Caucasian males were included to enable comparison of serum $L p(a)$ values in free-living Pygmies and Bantus and in healthy Caucasians to those in diseased Caucasians, using the same $\mathrm{Lp}(\mathrm{a})$ methodology.

\section{Laboratory Methods}

Serum $L_{p}(a)$ was determined using an anti-apo(a) polyclonal capture ELISA from Biopool (TintElize lipoprotein(a), Cat. No. 610220; Biopool AB, Umea, Sweden). The capture polyclonal anti-apo(a) antibody does not crossreact with plasminogen up to $1000 \mathrm{mg} / \mathrm{l}$. Lp (a) determinations in all population samples were performed using the TintElize Biopool kit, the assay being calibrated to total $\mathrm{Lp}$ (a) mass. Considering the lability of the Lp(a) lipoprotein particle [35], a maximum serum storage time of one year at $-70^{\circ} \mathrm{C}$ was respected. At our experimental conditions, it was documented by means of frozen human serum pools that storage did not affect $L_{p}(a)$ levels up to two years.

Cholesterol was determined enzymatically using CHODPAP reagents. Lipid analyses in the Belgian and Philippine population samples were performed at the University Hospital Leuven, Belgium, while all other determinations were performed at the Lipid Reference Laboratory of the University Hospital Rotterdam, The Netherlands. The Lipid Reference Laboratory (LRL) Rotterdam maintains total cholesterol standardization through the Lipid Standardization Panel of the Centers for Disease Control (CDC)-National Heart Lung and Blood Institute, Atlanta, Georgia. The LRL Rotterdam is also a permanent member of the Cholesterol Reference Method Laboratory Network (CRMLN) cstab. lished and coordinated by CDC [38]. The cholesterol values determined in the Leuven University Hospital were also found to be traceable to the Abell-Kendall reference method: in subsets of the samples it was documented that the mean average cholesterol bias was in accordance with current NCEP performance guidelines (bias $\leq 3 \%$ versus the Abell-Kendall reference method) [39].

\section{Statistical Methods}

Basic statistical analysis, analysis of variance (ANOVA), and Pearson correlation analyses were performed using the SPSS/PC+ package (version 5.0.2). Lp(a) and cholesterol data were logarithmically (natural) transformed in all population samples, and geometric means were calculated. Gender differences within populations were evaluated using Student's t-test. Lp(a) differences among population samples were evaluated by one-way ANOVA in either gender. The multiple range test of Student-Newman-Keuls was used for multiple-comparison of sample means. Age and body mass index (BMI)-adjustments of geometric $\mathrm{Lp}(\mathrm{a})$ and cholesterol means were performed by means of multiple linear regression analysis (MLR). BMI was defined as weight (in $\mathrm{kg}$ )/ height $\mathrm{t}^{2}$ (in $\mathrm{m}^{2}$ ). On the aggregated population level a weighted least squares MLR analysis was performed to investigate whether mean BMI and mean age could predict male and female mean serum cholesterol and Lp(a) levels across populations, respectively. A statistical significance level of $\alpha=0.05$ was adopted.

\section{RESULTS}

Table 1 displays mean ( $\pm S D$ ) age, BMI, and cholesterol per gender for the population samples under study. Significant age, BMI and cholesterol differences existed among all five population samples (ANOVA, $p<0.0001$ ).

Table 2 presents the unadjusted serum Lp(a) levels in African Pygmies and Bantus, compared with Caucasian and Asian population samples. Geometric mean Lp(a) levels were 274 and $289 \mathrm{mg} / \mathrm{l}$, respectively, in Bantu males $(\mathrm{n}=$ 93 ) and females $(n=115)$, and 220 and $299 \mathrm{mg} / \mathrm{l}$ in Pygmy males $(n=63)$ and females $(n=83)$. The gender difference was significant in Pygmies $(p=0.024)$ and not in Bantus. Likewise, Philippine females had higher $L p(a)$ values than males $(p=0.001)$. Lp (a) frequency distributions in Pygmy and Bantu were less skewed to the low concentration end, compared to Caucasian and Asian distributions (data not shown). In Pygmy males and females, respectively, $41 \%$ and $52 \%$ of the participants had Lp(a) levels above $300 \mathrm{mg} / \mathrm{l}$, compared with $47 \%$ and $55 \%$ of the Bantus. Serum Lp(a) levels did not significantly differ between Pygmies and Bantus. Multiple-comparison of $\operatorname{LnLp}(\mathrm{a})$ means demonstrated that Lp(a) levels in Pygmies and Bantus were in either gender significantly higher compared with those measured in any other population sample (SNK test; $p \leq 0.05$ ).

Overall upper reference ranges for men and women combined, defined as 75 th percentiles, were lowest in Asians (162 mg/l), intermediate in Caucasians (204 mg/l), and highest in African Pygmies and Bantus (479 mg/l). The 75th percentile in the diseased Caucasian group was 349 $\mathrm{mg} / \mathrm{L}$. (data not shown).

Lp(a) levels in Bantu males and females, and in Pygmy females were found to correlate with total cholesterol, LDLcholesterol (LDL-c), and apolipoprotein B (apo B) but not with age, BMI, systolic and diastolic blood pressure, HDLcholesterol, and apolipoprotein A-I (Table 3). Serum cholesterol was associated with age in Bantu males $(r=0.25$; $p=0.02$ ), while borderline significant in Pygmy males 
TABLE 1. Age, body mass index, and serum cholesterol levels in African Pygmies and Bantus, stratified by sex, compared with Asian and Caucasian population samples

\begin{tabular}{|c|c|c|c|c|c|c|c|}
\hline \multirow[b]{2}{*}{ Population } & \multirow[b]{2}{*}{$n$} & \multicolumn{2}{|c|}{$\begin{array}{c}\text { Age } \\
\text { (years) }\end{array}$} & \multicolumn{2}{|c|}{$\underset{\left(\mathrm{kg} / \mathbf{m}^{2}\right)}{\mathbf{B M I}}$} & \multicolumn{2}{|c|}{$\begin{array}{l}\text { Cholesterol } \\
(\mathrm{mmol} / \mathrm{l})\end{array}$} \\
\hline & & Mean & $\mathrm{SD}$ & Mean & SD & Mean & SD \\
\hline \multicolumn{8}{|l|}{ Men } \\
\hline \multicolumn{8}{|c|}{$\begin{array}{l}\text { Apparently healthy population samples } \\
\text { Africans }\end{array}$} \\
\hline Pygmies & 63 & 33.8 & 16.6 & 20.0 & 2.4 & 2.885 & 0.693 \\
\hline Bantus & 93 & 41.2 & 20.0 & 20.6 & 2.6 & 3.119 & 0.725 \\
\hline \multicolumn{8}{|l|}{ Caucasians } \\
\hline Belgians & 413 & 31.4 & 5.2 & 24.1 & 3.3 & 5.279 & 1.073 \\
\hline Hungarians & 200 & 42.2 & 12.3 & 26.8 & 3.9 & 6.017 & 1.223 \\
\hline \multicolumn{8}{|l|}{ Asians } \\
\hline Philippines & 96 & 43.7 & 10.7 & 23.8 & 3.4 & 5.301 & 0.981 \\
\hline \multicolumn{8}{|c|}{ Diseased (aucasians (Relgians) } \\
\hline CABG patients & 100 & 53.8 & 4.8 & 25.8 & 2.6 & 5.589 & 0.891 \\
\hline AMI patients & 50 & 59.5 & 11.6 & 25.5 & 3.1 & 5.551 & 1.025 \\
\hline \multicolumn{8}{|l|}{ Women } \\
\hline \multicolumn{8}{|c|}{ Apparently healthy population samples } \\
\hline \multicolumn{8}{|c|}{ Africans } \\
\hline Pygmics & 83 & 29.4 & 15.3 & 19.9 & 3.0 & 3.174 & 0.673 \\
\hline Bantus & 115 & 44.8 & 17.4 & 20.9 & 2.9 & 3.559 & 0.714 \\
\hline \multicolumn{8}{|l|}{ Caucasians } \\
\hline Belgians & 492 & 30.2 & 5.3 & 22.2 & 3.1 & 5.117 & 0.971 \\
\hline Hungarians & 200 & 40.3 & 10.5 & 26.0 & 5.6 & 5.702 & 1.162 \\
\hline \multicolumn{8}{|l|}{ Asians } \\
\hline Philippines & 99 & 46.9 & 10.4 & 23.1 & 3.9 & 5.433 & 1.155 \\
\hline
\end{tabular}

TABLE 2. Serum lipoprotein(a) levels in African Pygmies and Bantus, stratified by sex, compared with randomly selected Caucasian and Asian population samples

\begin{tabular}{|c|c|c|c|c|c|c|c|c|c|c|}
\hline \multirow[b]{3}{*}{ Population } & \multicolumn{10}{|c|}{$\begin{array}{c}\text { Lipoprotein(a) mass } \\
(\mathrm{mg} / \mathrm{l})\end{array}$} \\
\hline & \multirow[b]{2}{*}{$n$} & \multirow{2}{*}{$\begin{array}{c}\text { Geometric } \\
\text { mean }\end{array}$} & \multicolumn{7}{|c|}{ Percentile } & \multirow{2}{*}{$\begin{array}{c}>300 \mathrm{mg} / \mathrm{L} \\
(\%)\end{array}$} \\
\hline & & & 5 & 10 & 25 & 50 & 75 & 90 & 95 & \\
\hline \multicolumn{11}{|l|}{ Men } \\
\hline \multicolumn{11}{|c|}{ Apparently healthy population samples } \\
\hline \multicolumn{11}{|c|}{ Africans } \\
\hline Pygmies & 63 & $220^{a}$ & 37 & 62 & 141 & 234 & 424 & 530 & 758 & 41 \\
\hline Bantus & 93 & 274 & 50 & 78 & 180 & 259 & 525 & 826 & 972 & 47 \\
\hline \multicolumn{11}{|l|}{ Caucasians } \\
\hline Belgians & 413 & 70 & 6 & 10 & 30 & 71 & 216 & 455 & 566 & 20 \\
\hline Hungarians & 200 & 85 & 11 & 17 & 39 & 73 & 249 & 464 & 645 & 21 \\
\hline \multicolumn{11}{|l|}{ Asians } \\
\hline Philippines & 96 & $52^{a}$ & 9 & 12 & 24 & 52 & 127 & 269 & 323 & 7 \\
\hline \multicolumn{11}{|c|}{ Diseased Caucasians (Belgians) } \\
\hline CABG patients & 100 & 130 & 10 & 17 & 61 & 135 & 409 & 576 & 824 & 34 \\
\hline AMI patients & 50 & 113 & 14 & 35 & 58 & 97 & 249 & 599 & 651 & 19 \\
\hline \multicolumn{11}{|l|}{ Women } \\
\hline \multicolumn{11}{|c|}{ Apparently healthy population samples } \\
\hline \multicolumn{11}{|c|}{ Africans } \\
\hline Pygmies & 83 & 299 & 86 & 125 & 192 & 331 & 557 & 669 & 928 & 52 \\
\hline Bantus & 115 & 289 & 58 & 74 & 179 & 317 & 538 & 888 & 1111 & 55 \\
\hline \multicolumn{11}{|l|}{ Caucasians } \\
\hline Belgians & 492 & 67 & 7 & 11 & 27 & 67 & 186 & 411 & 553 & 16 \\
\hline Hungarians & 200 & 86 & 12 & 19 & 34 & 74 & 237 & 566 & 776 & 22 \\
\hline \multicolumn{11}{|l|}{ Asians } \\
\hline Philippincs & 99 & 86 & 18 & 21 & 44 & 88 & 176 & 294 & 399 & 9 \\
\hline
\end{tabular}

$" p \leq 0.05$ for gender differences within population samples (Student's $t$-test). 
TABLE 3. Pearson correlations of $\operatorname{LnLp}(\mathrm{a})$ with anthropometric data and serum lipids in African Pygmies and Bantus, with respect to gender

\begin{tabular}{|c|c|c|c|c|}
\hline \multirow[b]{2}{*}{ Variable } & \multicolumn{2}{|c|}{ Bantu } & \multicolumn{2}{|c|}{ Pygmy } \\
\hline & $\begin{array}{c}\text { Males } \\
n=92\end{array}$ & $\begin{array}{l}\text { Females } \\
n=113\end{array}$ & $\begin{array}{c}\text { Males } \\
n=63\end{array}$ & $\begin{array}{c}\text { Females } \\
n=83\end{array}$ \\
\hline Age & -0.06 & 0.06 & -0.10 & 0.16 \\
\hline BMI & 0.12 & -0.15 & 0.06 & 0.10 \\
\hline SBP & -0.07 & -0.09 & -0.01 & 0.09 \\
\hline DBP & -0.06 & 0.15 & -0.04 & 0.02 \\
\hline Heart rate & -0.03 & -0.04 & 0.13 & 0.08 \\
\hline Apo A-I & 0.11 & -0.00 & -0.00 & -0.05 \\
\hline HDL-cholesterol & 0.06 & -0.02 & -0.04 & 0.12 \\
\hline Apo B & $0.38^{\circ}$ & $0.31^{b}$ & 0.19 & $0.31^{h}$ \\
\hline LDL-cholesterol & $0.50^{c}$ & $0.39^{c}$ & 0.03 & $0.35^{b}$ \\
\hline Cholesterol & $0.35^{\circ}$ & $0.28^{b}$ & 0.06 & $0.78^{a}$ \\
\hline Netto triglycerides & $-0.26^{a}$ & -0.02 & 0.13 & -0.13 \\
\hline
\end{tabular}

$$
\begin{aligned}
" p & <0.05 . \\
p p & <0.01 . \\
p p & <0.001 .
\end{aligned}
$$

$(r=0.22 ; p=0.08)$. In contrast, serum cholesterol was not significantly associated with age in Pygmy respectively Bantu females (data not shown).

Table 4 depicts age- and BMI-adjusted geometric Lp(a) and cholesterol means per gender for the population samples studied. P-values are given, versus the Belgian popula- tion sample, the latter being the reference population sample in the MLR analysis. Pygmy and Bantu concentrations differed significantly from Belgian levels ( $p<0.0001$ ), Pygmies and Bantus having the lowest serum cholesterol, and the highest serum Lp(a) levels among the population samples studied. Philippine males had Lp(a) levels that were significantly lower compared with those in Belgian males, while Hungarian females displayed significantly higher Lp(a) levels compared to Bclgian females. Both Hungarian males and females had significantly higher cholesterol values compared to Belgians. Age- and BMI-adjusted geometric $L p(a)$ means were 2.8-and 4.3-fold higher in male respectively female Pygmies compared to Belgian males and females, and 3.5- and 3.9-fold higher in male and female Bantus $(p<0.0001)$. Finally, age-and BMI-adjusted serum Lp(a) levels in diseased Belgian males were significantly higher than in apparently healthy Belgian males: $131 \mathrm{mg} /$ 1 in CABG patients and $114 \mathrm{mg} / \mathrm{l}$ in AMI patients, compared with $72 \mathrm{mg} / 1$ in healthy male participants.

MLR analysis pointed out that BMI, age, and ethnicity explained $12 \%$ and $17 \%$ of serum $\mathrm{Lp}(\mathrm{a})$ variance in males and females, respectively, compared with $60 \%$ and $51 \%$ of serum cholesterol variance. BMI and age alone explained maximum 3\% of $\mathrm{Lp}(\mathrm{a})$ variance. After adjusting for ethnicity $\mathrm{BMI}$ remained a borderline significant predictor in either gender (BMI in males: $p=0.08$; BMI in females: $p=0.09)$, in contrast with age. Moreover, Table 5 demon-

\begin{tabular}{|c|c|c|c|c|c|}
\hline Population & $n$ & $\begin{array}{c}\text { Cholesterol } \\
(\mathrm{mmol} / \mathrm{l})\end{array}$ & $\begin{array}{l}p \text {-Value vs. } \\
\text { Belgians of the } \\
\text { same gender }\end{array}$ & $\begin{array}{c}\text { Lipoprotein }(a) \\
(\mathbf{m g} / 1)\end{array}$ & $\begin{array}{c}p \text { Value vs. } \\
\text { Belgians of the } \\
\text { same gender }\end{array}$ \\
\hline \multicolumn{6}{|l|}{ Men } \\
\hline \multicolumn{6}{|c|}{ Apparently healthy population samples } \\
\hline \multicolumn{6}{|c|}{ Africans } \\
\hline Pygmies & 63 & 3.017 & $<0.0001$ & 204 & $<0.0001$ \\
\hline Bantus & 93 & 3.159 & $<0.0001$ & 253 & $<0.0001$ \\
\hline \multicolumn{6}{|l|}{ Caucasians } \\
\hline Belgians & 413 & 5.336 & - & 72 & - \\
\hline Hungatians & 200 & 5.659 & 0.0012 & 88 & NS \\
\hline \multicolumn{6}{|l|}{ Astans } \\
\hline Philippines & 96 & 5.159 & NS & 51 & 0.0243 \\
\hline \multicolumn{6}{|c|}{ Diseased Caucasians (Belgians) } \\
\hline CABG patients & 100 & 5.159 & NS & 131 & 0.0003 \\
\hline AMI patients & 50 & 4.895 & 0.0164 & 114 & 0.0545 \\
\hline \multicolumn{6}{|l|}{ Women } \\
\hline \multicolumn{6}{|c|}{ Apparently healthy population samples } \\
\hline \multicolumn{6}{|c|}{ Africans } \\
\hline Pygmies & 83 & 3.241 & $<0.0001$ & 289 & $<0.0001$ \\
\hline Bantus & 115 & 3.445 & $<0.0001$ & 264 & $<0.0001$ \\
\hline \multicolumn{6}{|l|}{ Caucasians } \\
\hline Belgians & 492 & 5.104 & - & 67 & - \\
\hline Hungarians & 200 & 5.296 & 0.036 & 90 & 0.0129 \\
\hline \multicolumn{6}{|l|}{ Asians } \\
\hline Philippines & 99 & 5.111 & NS & 81 & NS \\
\hline
\end{tabular}

TABLE 4. Age- and BMI-adjusted geometric mean values of serum lipoprotein(a) and serum cholesterol in African Pygmies and Bantus, stratified by sex, compared with randomly selected Caucasian and Asian population samples

Abbreviation: NS $=$ not significant. 
TABLE 5. Weighted least squares multiple linear regression analysis in aggregated Caucasian, Asian, and African population samples $(n=5)$, stratified by sex, with mean serum lipoprotein(a) and mean serum cholesterol as dependent variables, and with mean age and mean $\mathrm{BMI}$ as independent variables

\begin{tabular}{|c|c|c|c|c|}
\hline Dependent variable & Predictors & Coefficient & S.E. & $p$ Value \\
\hline \multicolumn{5}{|l|}{ Men } \\
\hline Mean Ln Lp(a) & Mean BMI $\left(\mathrm{kg} / \mathrm{m}^{2}\right)$ & -0.1873 & 0.1174 & NS \\
\hline \multirow{2}{*}{ (Ln $\mathrm{mg} / \mathrm{l}$ ) } & Mean age (year) & 0.0316 & 0.0447 & NS \\
\hline & Constant & 7.8378 & 2.9511 & NS \\
\hline \multirow{3}{*}{$\begin{array}{l}\text { Mean Ln cholesterol } \\
\text { (Ln mmol/l) }\end{array}$} & Mean BMI $\left(\mathrm{kg} / \mathrm{m}^{2}\right)$ & 0.1148 & 0.0250 & 0.04 \\
\hline & Mean age (year) & -0.0085 & 0.0095 & NS \\
\hline & Constant & -0.8720 & 0.6284 & NS \\
\hline \multicolumn{5}{|l|}{ Women } \\
\hline Mean Ln $L_{p}(a)$ & Mean BMI $\left(\mathrm{kg} / \mathrm{m}^{2}\right)$ & -0.2071 & 0.1610 & NS \\
\hline \multirow{2}{*}{$(\mathrm{Ln} \mathrm{mg} / \mathrm{l})$} & Mean age (year) & 0.0510 & 0.0445 & NS \\
\hline & Constant & 7.4687 & 3.4060 & NS \\
\hline \multirow{3}{*}{$\begin{array}{l}\text { Mean Ln cholesterol } \\
\text { (Ln } \mathrm{mmol} / \mathrm{l} \text { ) }\end{array}$} & Mean BMI $\left(\mathrm{kg} / \mathrm{m}^{2}\right)$ & 0.0885 & 0.0445 & NS \\
\hline & Mean age (year) & -0.0087 & 0.0123 & NS \\
\hline & Constant & -0.1421 & 0.9421 & NS \\
\hline \multicolumn{5}{|l|}{ Men and women } \\
\hline Mean Ln Lp(a) & Sex (female) & -0.1272 & 0.3170 & NS \\
\hline \multirow{3}{*}{$(\mathrm{Ln} \mathrm{mg} / \mathrm{l})$} & Mean BMI $\left(\mathrm{kg} / \mathrm{m}^{2}\right)$ & -0.1954 & 0.0812 & 0.05 \\
\hline & Mean age (year) & 0.0435 & 0.0258 & NS \\
\hline & Constant & 7.5961 & 1.9049 & 0.007 \\
\hline
\end{tabular}

Abbreviation: NS $=$ not significant.

strates that at the aggregated level, i.e., across the population samples studied, overall mean BMI was negatively correlated with overall mean $L p(a)$ levels $(p=0.05)$ if men and women were grouped.

\section{DISCUSSION}

The Pygmies studied are pure hunter-gatherers and are the Aborigines in Africa south of the Sahara. They were overrun by the Bantu who, from 1200-1400 A.D. gradually spread from the upper Nile Valley and the region of Lake Chad southward and westward over the continent [32]. Up to now, Pygmies live in isolated groups annong the Bantu and along the Equator. As described by Kesteloot et al. $[33,40]$, the characteristic diminutive Pygmy stature together with the consistent Pygmy body measurements, lifestyle factors and serum lipid levels compared to previous reports [32], are a reflection of the homogeneity of the Pygmy race and of the fact that a representative sample was taken. The Pygmy sample investigated, though partly consisting of related individuals as children were included, was derived from four different communities living in and nearby the Dja reservation in South-West Cameroon. Due to the high participation rate the Pygmy sample is a good representation of the current Pygmy cohabitation in those specific regions. However, the representativeness for the total African Pygmy population is unknown. The same holds for the Bantu sample investigated: volunteers from three neighboring communities, mainly entered on a first-come, first-served basis and partly containing relatives, were stud- ied. Notwithstanding the fact that the Bantu population sample was not randomly gathered, it reflects the Bantu cultures from the Mecasse and the Lolodorf region, and the city of Bengbis.

In this study, we focused upon the genetically determined $\mathrm{Lp}$ (a) lipoprotein risk factor, in relation to the modifiable serum cholesterol risk factor and to ethnicity. Notable features of our study are the exceptionally low mean serum cholesterol levels in Pygmies, the absent or minor cholesterol increase with estimated age, as well as the two-to fivefold higher mean Lp(a) levels (Tables 2 and 4) compared with Asians and Caucasians. Bantus had the same mean Lp(a) level as Pygnies, while age- and BMI-adjusted serum cholesterol levels were approximately $5 \%$ higher both in males and females, and increased significantly with age in Bantu males. From Table 2 it can be seen that $41-55 \%$ of Pygmies and Bantus had scrum Lp(a) levels above $300 \mathrm{mg} /$ 1 , the universally accepted upper reference limit in Caucasians. As presence of CHD is very unlikely in African Pygmies [32] and Bantus, the high serum Lp(a) concentrations samples must either be counteracted by other factors, or be in itself an insufficient cause for developing atherosclerosis. Consequently, we agree with orhers $[41,42]$ that for identifying subjects at increased risk of coronary heart disease, ethnicity-related cutoff values, based on 75 th percentiles, should be used for Lp(a).

Using MLR serum Lp(a) variances could be explained up to $12 \%$ and $17 \%$ in males and females, respectively, across the healthy population samples studied, and were predicted exclusively by ethnicity and barely by age or BMI. However, 
at the aggregated level, mean BMI was negatively correlated with mean $L p(a)$ if men and women were combined, while no significant correlation was observed with mean age (Table 5). Finally, the tight univariate correlations demonstrated with total cholesterol, apo B and LDL-c in Pygmies and Bantus could be explained by the high relative percentage of $L_{p}(a)$-cholesterol and $L_{p}(a)$-apo $B$ compared with Asians and Caucasians (Table 3).

The large differences in serum $L p(a)$ between $\Lambda$ frican Pygmies and Bantus compared with Asians $[43,44]$ and Caucasians $[10 \quad 13,41,43,45,46]$, and the absence of association with many other variables except serum lipids, are consistent with previous reports that state that $\mathrm{Lp}(\mathrm{a})$ levels are largely genetically determined $[1,5,6]$. Also, the height and distribution of the serum $L p(a)$ levels in Pygmies and Bantus seem to be comparable or even higher than those described in Nigerians [43], Congolese [47], Sudanese [48] and American blacks $[19,25,49-53]$. The high Lp(a) levels in blacks, without corresponding high prevalence of CHD, suggest that race and gender differences in apo(a) phenotypes, hemostatic activity, or other unrelated factors may contribute to this paradox. However, from twin studies it became clear that neither behavioral or environmental correlates, nor variation in the apo(a) size phenotype appeared to explain the higher mean $L p(a)$ levels among blacks compared to whites [7]. Rather these findings corroborate the hypothesis that $\operatorname{Lp}(\mathrm{a})$ is a continuous supplier of liver cholesterol to peripheral endocrine organs independent of triglycerides or dietary cholesterol intake, being preferentially preserved during human evolution in black African populations of which the food supply was not as regulated as that of Caucasian and Asian populations. In contrast, in civilized human populations, Lp(a) may have lost its phylogenetical importance since other cholesterol-rich lipoproteins, notably LDL, are highly abundant. Moreover, potential adverse effects of high Lp(a) levels should become overt especially in these civilized populations. This may be in line with the significant shift-to-the-right of the $L_{p}($ a) distributions (Table 2) and of the geometric means (Table 4) in Caucasian CABG and AMI patients, respectively, compared with healthy Caucasians, notwithstanding similar (CABG group) or even lower (AMI group) mean cholesterol levels in the diseased Caucasian groups (Table 4). The shift-tothe right is also in accordance with the findings of numerous other authors $[6,22]$. Although $\mathrm{CHD}$ is a multifactorial disease, the 1.6- and 1.8-fold higher, respectively, adjusted $\mathrm{Lp}$ (a) means in diseased compared with healthy Caucasians may he elements aggravating the atherosclerosis risk of these subjects and contributing to their disease. In contrast, the high $\mathrm{Lp}$ (a) levels in Pygmies and Bantus without concomitant high prevalence of CHD are difficult to understand. Yet, according to Maher et al. [54] Lp(a) is especially atherogenic in combination with high (LDL-) cholesterol levels or other acquired risk factors, e.g., due to Westernization [29-31], that can nurture $\mathrm{Lp}$ (a) into a more potent risk factor. To draw firm conclusions regarding the Lp(a) pathogenicity in Pygmies, Bantus, and other population. samples prospective studies are warranted that document $\mathrm{Lp}$ (a) atherogenicity and its determinants in different populations.

Major strengths of this study are the fact that serum $L p$ (a) levels were obtained using one and the same method in all population samples, and were determined in frozen sera that were adequatcly stored for lcss than onc ycar. Thereforc, storage time and temperature did not confound the measured Lp (a) results [35]. Limitations of this study are related to the cross-sectional study design and the relatively small sample sizes. Moreover, Pygmy and Bantu samples were not completely randomized, in contrast with the Asian and Caucasian samples. Consequently, extrapolation of these data to whole populations should be done with caution. Also, the diseased Caucasians represent two strongly selected groups that were, with the exception of BMI and age, not matched or adjusted for other cardiovascular risk factors.

We conclude that African Aboriginal Pygmies and Bantus have serum $\mathrm{Lp}_{\mathrm{p}}$ (a) levels that are comparable, with adjusted $\mathrm{Lp}(\mathrm{a})$ means being up to fivefold higher compared with Asian and Caucasian means. In contrast, adjusted serum cholesterol means were 0.57- to 0.67-fold the Caucasian and Asian means. In the light of the virtual absence of CHD in Aboriginal African Pygmies and Bantus, high serum $L p(a)$ levels do not seem to be very deleterious in these population samples. Consequently, ethnicity-related upper reference values should be used for $\mathrm{Lp}(\mathrm{a})$. Also, longitudinal studies are warranted to determine the pathogenicity of $\mathrm{Lp}(\mathrm{a})$ in different populations with variable interrelationships between nature and nurture.

The authors are grateful to Drs. P. Jacques and J. Brouwers of the "Centres de Services Interenterprises-Médecine du Travail" from Flanders and Wallonia, Belgium, respectively; to Professor G. Biró from the National Institute of Food Hygiene and Nutrition, Budapest, Hungary; and to Dr. Cabral, director from the Philippine Heart Center, Quezon City, Philippines for delivering randomized sera from unrelated subjects. The authors also wish to thank Ms. Bea van den Berg for doing the analytical work.

\section{References}

1. Marcovina SM, Levine DM, Lippi G. Lipoptotein(a): Structure, measurement, and clinical significance. In: Rifai N, Warnick GR, Eds. Laboratory Measurements of Lipids, Lipoproteins and Apolipoproteins. Washington, DC: AACC Press; 1994: 235-263.

2. McLean JW, Tomlinson JE, Kuang WJ, et al. cDNA sequence of human apolipoprotein(a) is homologous to plasminogen. Nature (Lond) 1987; 300: 132-137.

3. Scanu AM. Structural and functional polymorphism of lipoprotein(a): Biological and clinical implications. Clin Chem 1995; 41: 170-172.

4. Trommsdorff M, Kochl S, Lingenhel A, et al. A pentanucleotide repeat polymorphism in the $5^{\prime}$ control region of the apolipoprotein(a) gene is associated with lipoprotein(a) plasma 
concentration in Caucasians. J Clin Invest 1995; 96: 150157.

5. Boerwinkle E, Leffert CC, Lin J, et al. Apolipoprotein(a) gene accounts for greater than $90 \%$ of the variation in plasma lipoprotein(a) concentrations. J Clin Invest 1992; 90: 52-60.

6. Dahlén GH. Review article and viewpoint. Lp(a) lipoprotein in cardiovascular disease. Atherosclerosis 1994; 108: 111126.

7. Selby JV, Austin MA, Sandholzer C, et al. Environmental and behavioral influences on plasma lipoprotein(a) concentrations in women twins. Prev Med 1994; 23: 345-353.

8. Cobbaert C, Deprost L, Mulder P, Rombaut K, Gijsels G, Kesteloot H. Pubertal serum lipoprotein(a) and its correlates in Belgian schoolchildren. Int J Epidemiol 1995; 24: 78-87.

9. Muls E, Kempen K, Vansant G, Cobbaert C, Saris W. The effects of weight loss and apolipoprotein $E$ polymorphism on serum lipids, apolipoproteins A-I and B, and lipoprotein(a). Int J Obesity 1993; 17: 711-716.

10. Slunga L, Asplund K, Johnson O, et al. Lipoprotein(a) in a randomly selected 25-64 years old population: The Northern Sweden Monica Study. J Clin Epidemiol 1993; 46: 617-624.

11. Brown SA, Hutchinson R, Morrisett J, et al. Plasma lipid, lipoprotein cholesterol, and apoprotein distributions in selected US communities. Arterioscler Thromb 1993; 13: 1139-1158.

12. Jenner JL, Orodvas JM, Lamon-Fava S, et al. Effects of age, sex, and menopausal status on plasma lipoprotein(a) levels: The Framingham Offspring Study. Circulation 1993; 87: $1135-1141$.

13. Heinrich J, Sandkamp M, Kokott R, et al. Relationship of lipoprotein(a) to variables of coagulation and fibrinolysis in a healthy population. Clin Chem 1991; 37: 1950-1954.

14. Davies M, Rayman G, Day J. Increased incidence of coronary disease in people with impaired glucose tolerance: Link with increased lipoprotein(a) concentrations? Br Med J 1992; 304: 1610-1611.

15. Nakata H, Horita K, Eto M. Alteration of lipoprotein(a) concentration with glycemic control in non-insulin-dependent diabetic subjects without diabetic complications. Metabolism 1993; 42: 1323-1326.

16. Jenkins AJ, Steele JS, Janus ED, Best JD. Increased plasma apolipoprotein(a) levels in IDDM patients with microalbuminuria. Diabetes 1991; 40: 787-790.

17. Karádl I, Romics L, Palos G, et al. Lp(a) lipoprotein concentration in serum of patients with heavy proteinuria of different origin. Clin Chem 1989; 35: 2121-2123.

18. Folsom AR, Wu KK, Davis CE, et al. Population correlates of plasma fibrinogen and factor VII, putative cardiovascular risk factors. Atherosclerosis 1991; 91: 191-205.

19. Howard BV, Le NA, Belcher JD, et al. Concentrations of I p (a) in black and white young adults: Relations to risk fartors for cardiovascular disease. Ann Epidemiol 1994; 4: 341 350.

20. Gurakar A, Hoeg JM, Kostner G, et al. Levels of lipoprotein $\mathrm{Lp}$ (a) decline with neomycin and niacin treatment. Atherosclerosis 1985; 57: 293-301.

21. Carlson LA, Hamsten A, Asplund A. Pronounced lowering of serum levels of lipoprotein $L_{p}(a)$ in hyperlipidaemic subjects treated with nicotinic acid. J Intern Med 1989; 226: 271276.

22. Kostner GM. The physiological role of Lp(a). In: Scanu AM, Ed. Lipoprotein(a). San Diego: Academic Press Inc; 1990: $183-204$.

23. Austin MA, Hokanson JE. Epidemiology of triglycerides, small dense low-density lipoprotein, and lipoprotein(a) as risk factors for coronary heart disease. Med Clin North Am 1994; 78(1): 99-115. (Review)
24. Schreiner PJ, Chambless LE, Brown SA, Watson RL, 'Toole J, Heiss G. Lipoprotein (a) as a correlate of stroke and transient ischemic attack prevalence in a biracial cohort: The ARIC study. Atherosclerosis risk in communities. Ann Epidemiol 1994; 4: 351-359.

25. Schreiner PJ. Lipoprotein(a) as a risk factor for preclinical atherosclerotic disease in a biracial cohort: The Atherosclerosis Risk in Communities (ARIC) study. Chem Phys Lipids 1994; 67-68: 405-410.

26. Rath $M$, Niendorf $A$, Reblin $T$, et al. Detection and quantification of lipoprotein(a) in the arterial wall of 107 coronary bypass patients. Arteriosclerosis 1989; 9: 579-592.

27. Edelberg J, Pizzo SV. Lipoprotein(a) regulates plasmin generation and inhibition. Chem Phys Lipids 1994; 67-68: 363368.

28. Palabrica TM, Liu AC, Aronovitz MJ, et al. Antifibrinolytic activity of apolipoprotein(a) in vivo: Human apolipoprotein(a) transgenic micc are resistant to tissue plasminogen activator-mediated thrombolysis. Nature Medicine 1995; 1: $256-259$.

29. Bhatnagar D, Anand IS, Durrington PN, et al. Coronary risk factors in people from the Indian subcontinent living in West London and their siblings in India. Lancet 1995; 345: 405409.

30. Williams B. Westernized Asians and cardiovascular disease: Nature or nurture? Lancet 1995; 345: 401-402. (Comment)

31. Gracey M. New World Syndrome in Western Australian Aborigines. Clin Exp Pharmacol Plyysiol 1995; 22: 220-225.

32. Mann GV, Roels OA, Price DL, Merrill JM. Cardiovascular disease in African Pygmies. A survey of the health status, serum lipids and diet of Pygmies in Congo. J Chron Dis 1962; 15: $341-371$.

33. Kesteloot H, Ndam ECN, Sasaki S, Kowo M, Seghers V. A survey of blood pressure distribution in Pygmy and Bantu populations in Cameroon. Hypertension 1996; 27: 108-113.

34. Kowo PK, Goubau P, Ndam ECN, et al. Prevalence of hepatitis $\mathrm{C}$ virus and other blood-borne viruses in Pygmies and neighbouring Bantus in southern Cameroon. Transactions of the Royal Society of Tropical Medicine and Hygiene 1995; 89: 484-486.

35. Berg K. Confounding results of $L p(a)$ lipoprotein measurements with some test kits. Clin Genet 1994; 46: 57-62.

36. Cobbaert C, Biró G, Antal M, et al. Serum lipoprotein(a) levels in a Hungarian population. Atherosclerosis 1994; 108(Suppl.): 192. (Abstract)

37. Cobbaert C, Sergeant P, Meyns B, Scézsi J, Kesteloot H. Time course of serum $\mathrm{Lp}(\mathrm{a})$ in men after coronary artery bypass grafting. Acta Cardiologica 1992; XLVII: 529-542.

38. Myers GL, Cooper GR, Henderson LO, Hassemer DJ, Kimberly MM. Standardization of lipid and lipoprotein measurements. In: Rifai N, Warnick GR, Eds. Laboratory Measurements of Lipids, Lipoproteins and Apolipoproteins. Washington, DC: AACC Press; 1994: 177-205.

39. Expert Panel on Detection, Evaluation, and Treatment of High Blood Cholesterol in Adults. Summary of the Second Report of the National Cholesterol Education Program (NCEP) Expert Panel on detection, evaluation and treatment of high blood cholesterol in adults. Adult Treatment Panel II. J Am Med Assoc 1993; 34: 193-201.

40. Kesteloot H, Ndam ECN, Kowo M, et al. Serum lipid levels in a Pygmy and Bantu population sample from Cameroon. (Submitted)

41. Marcovina SM, Albers JJ, Jacobs DR, et al. Lipoprotein(a) concentrations and apolipoprotein(a) phenotypes in Caucasians and African Americans. The Cardia Study. Arterioscler Thromb 1993; 13: 1037-1045. 
42. Leino A, Impivaara $O$, Kaitsaari $M$, Järvisalo J. Serum concentration of apolipoprotein A-I, apolipoprotein B and lipoprotein(a) in a population sample. Clin Chem 1995; 41: $1633-$ 1636.

43. Cobbaert C, Kesteloot H. Serum lipoprotein(a) levels in racially different populations. Am J Epidemiol 1992; 136: 441449.

44. Nago N, Kayaba K, Hiraoka J, ct al. Lipoprotein(a) levels in the Japanese population: Influence of age, sex and relation to atherosclerotic risk factors. Am J Epidemiol 1995; 141: 815821.

45. Cigolini M, Seidell JC, Zenti MG, et al. Serum Lp(a) levels in randomized healthy men from different European countrics. Eur J Epidemiol 1993; 9: 497-503.

46. Bovet P, Rickenbach M, Wietlisbach V, et al. Comparison of serum lipoprotein(a) distribution and its correlates among black and white populations. Int J Epidemiol 1994; 23: 2027.

47. Parra HJ, Luyeye I, Bouramoue C, et al. Black-white differences in serum Lp(a) lipoprotein levels. Clin Chim Acta 1987; 168: 27-31.

48. Sandholzer C, Hallman DM, Saha N, et al. Effects of the apoli- poprotein(a) size polymorphism on the lipoprotein(a) concentration in 7 ethnic groups. Hum Genet 1991; 86: 607614.

49. Guyton JR, Dahlén GH, Patsch W, et al. Relationship of plasma lipoprotein $\mathrm{Lp}(\mathrm{a})$ levels to race and to apolipoprotein B. Arteriosclerosis 1985; 5: 265-272.

50. Levitsky LL, Scanu AM, Gould SH. Lipoprotein(a) levels in black and white children and adolescents with IDDM. Diabetes Care 1991; 14: 283-287.

51. Srinivasan SR, Dahlén GH, Jarpa RA, et al. Racial (blackwhite) differences in serum lipoprotein(a) distributions and its relation to parental myocardial infarction in children: Bogalusa Heart Study. Circulation 1991; 84: 160-167.

52. Heyden S, Von Eckardstein A, Schulte H, Schneider K, Assmann G. Raised lipoprotein(a) in hypercholesterolaemic black students compared to age-matched whites in North and South Carolina. Int J Epidemiol 1994; 23: 301-306.

53. Knapp RG, Schreiner PJ, Sutherland SE, et al. Serum lipoprotein(a) levels in elderly black and white men in the Charleston Heart Study. Clin Genet 1993; 44: 225-231.

54. Maher VMG, Brown BG. Lipoprotein(a) and coronary heart disease. Curr Opin Lipid 1995; 6: 229-235. 